\title{
Acidity level control formulation of roselle tea functional drinks based on variations in the addition of flower petals and sugar type
}

\author{
*Purbowati, I.S.M., Karseno. and Maksum, A. \\ Food Processing Technology Laboratory, Department of Agricultural Technology, Faculty of Agriculture, \\ Universitas Jenderal Soedirman, Dr. Suparno Street, Karangwangkal, Purwokerto 53123, Indonesia
}

\begin{abstract}
Article history:
Received: 18 October 2019

Received in revised form: 7

December 2019

Accepted: 14 December 2019

Available Online: 27 January 2020
\end{abstract}

Keywords:

Roselle,

Hibiscus sabdariffa,

Sugar,

Functional drink

\section{DOI:}

https://doi.org/10.26656/fr.2017.4(3).343

\begin{abstract}
Roselle (Hibiscus sabdariffa) tea was a phenolic acid and anthocyanin enriched-functional drink. The high antioxidant content of roselle tea benefits to prevent degenerative diseases, such as diabetes. The acidity flavor was due to the high content of phenolic compounds and anthocyanins. This led to the addition of low glycemic index sugar. Therefore, it is necessary to understand the formulation between the variation of flower petals and sugar type's addition. The purpose of this study was to find out the best effect of petal flowers and sugar type addition towards physical, chemical and sensory quality of roselle tea. The research design used in this study was Complete Randomized trial with 2 (two) factors and 3 replications. The first factor comprises between flower petals addition (R) towards water (w/v) of 1:100 (R1), 4:100 (R2), 7:100 (R3), and 10:100 (R4). The second factor was sugar type $(G)$ : cane sugar $(G 1)$ which comprises coconut sugar $(G 2)$ and corn sugar (G3). Observed variables in this study were physical and chemical variables (color, total phenol, anthocyanin and $\mathrm{pH}$ level), and sensory variable (acidity and favorable level). The best combination was R4G1 with characteristics of anthocyanins of $5.25 \mathrm{mg} / 100 \mathrm{~mL}$; phenol of $24.35 \mathrm{mg} / 100 \mathrm{~mL}$; $\mathrm{pH}$ of 2.6 ; $\mathrm{L}$ amounted to 24.70
\end{abstract}

\section{Introduction}

Roselle is an annual herb that can reach heights of $0.5-3$ meters. The stem is round, erect, woody, and redcolored. The leaves are singular, oval-shaped, bluntended, jagged edges, and notched base. The leaves are 6 $-15 \mathrm{~cm}$ long and $5-8 \mathrm{~cm}$ wide. The stalks are green, with a length of $4-7 \mathrm{~cm}$. (Maryani and Kristiana, 2008)

Awhin (2012) and Babajide et al. (2014) stated that roselle petals contain several vitamin and mineral such as vitamin $\mathrm{C}$, calcium, niacin, riboflavin, and flavonoids. According to Olatunji and Juwe (2013), roselle could lower blood viscosity, stimulate bowel movement, and improve the health status of diabetic patients.

The effectiveness of roselle petals in diabetic treatment is due to high antioxidant content. According to Purbowati et al. (2015) extraction used with $70 \%$ ethanol resulted in roselle petals containing phenolic compounds $(19.45 \pm 0.32 \mathrm{mg} / \mathrm{g})$, anthocyanin $(13.51 \pm 0.03$ $\mathrm{mg} / \mathrm{g})$ and vitamin $\mathrm{C}(20.47 \pm 0.34 \mathrm{mg} / \mathrm{g})$. The majority of phenol content in roselle extract is anthocyanin compounds, such as delphinidin-3-0glucoside, delphinidin-3-0-sambubioside dan cyanidin-3-0sambubioside (Nerantzaki et al., 2011).
Kharismawati et al. (2015) stated that the more intense red colored within roselle petals, the more acid and higher anthocyanin level. Antioxidants are molecules that capable to slow down or prevent from the oxidation of other molecules. Antioxidants activity are correlated with total phenol, Vitamin C, and anthocyanin content (Purbowati et al., 2018)

In order to make it easier to use, the bioactive components in roselle petal must be extracted out of the cell. Conventional extraction techniques such as boiling, heating, and reflux can be used to extract phenolic compounds. The weakness of this conventional technique was the damage of phenol compounds due to oxidation, hydrolysis and ionization reactions during the extraction process. This was mainly because with this method the time used was usually long result in damage to phenol compounds extracted out. Therefore, other methods such as Supercritical Subcritical Water Extraction, Ultrasonic Assisted Extraction, Carbon dioxide Extraction, and Microwave-Assisted Extraction (MAE) are more attractive alternatives than conventional ones.

Based on the characteristic of roselle bioactive compound, MAE is an effective extraction technique to 
withdraw dissolved materials within roselle petals (Purbowati et al., 2016). This technology is suitable for thermolabile compound's extraction due to its better temperature control compared to conventional heating process. Extraction with MAE does not need a high temperature; therefore, it will not denature the components within. Another advantage of MAE is a shorter extraction time (Li et al., 2009). Among these methods, MAE is also a simple and economical method to extract bioactive compounds from plants. Product recovery using MAE is determined by the heating effect that occurs due to the rotation of the dipole from the solvent in the microwave (Zhang et al., 2005; Hemwimon et al., 2007). According to Wang et al. (2010) optimum condition for extracting flavonoids from Radix Pueraria was: ethanol concentration $70 \%$, solvent volume $35 \mathrm{~mL}$, microwave power $255 \mathrm{~W}$ and 6.5 mins of extraction time. Respond yield was $8.37 \mathrm{mg} / \mathrm{g}$. Solvent volume increase could make excessive swelling of the material by water and absorbing the effective constituent.

The production of roselle functional drinks needs the addition of sweetening ingredient in a great amount to improve the taste and aroma. The sour taste due to high bioactive compounds content within roselle extract needs to be revamped so that it is acceptable to consumers. According to Cahyadi (2008), sugar is added in order to improve the taste and scent, thus the sweetness can increase the delicacy.

Coconut sugar has superior benefits compared to cane sugar in terms of its glycemic index. Septiana and Dwiyanti (2009) stated that glycemic index is a value that shows the potential increase in blood sugar from carbohydrates available in food or simply can be said as a level of food ranking according to its effect on blood sugar levels. Coconut sugar has a glycemic index of 35, which is classified in the low category $(<55)$. On the other hand, cane sugar has a glycemic index of 64 , nearly classified in the high category $(>70)$. Besides the low glycemic index, coconut sugar contains several nutritional compounds such as amino acid and vitamin. Low glycemic index and the addition of nutritional compounds that are expected to improve drink's efficacy. Also, according to Karseno et al. (2018) coconut sugar has antioxidant activity as high as $40 \%$.

Therefore, it is necessary to study about roselle functional drink formulation using MAE which produces a high content of bioactive components with a level of acidity that is still acceptable for consumers. The purpose of this study was to determine that effect of variation in the addition of roselle flower petals and sugar type towards physical, chemical, and sensory characteristics of the roselle functional drinks produced.

\section{Materials and methods}

\subsection{Materials}

The materials used in this study is roselle petals (bought at Beringharjo Market, Yogyakarta Indonesia), cane sugar, coconut sugar, and corn sugar. In addition to these ingredients, water as a solvent was used. While the materials used in the physicochemical analysis include acidic ethanol, 10\% Folin-Ciocalteu reagent, 7.5\% $\mathrm{Na}_{2} \mathrm{CO}_{3}$ solution, Gallic acid and distilled water.

The research design used in this study was complete randomized trial with 2 (two) factors and 3 replications. The first factor comprises between flower petals addition (R) towards water (w/v) of 1:100 (R1), 4:100 (R2), 7:100 (R3), and 10:100 (R4). The second factor was sugar type (G): Cane sugar (G1) which comprises coconut sugar (G2) and corn sugar (G3).

\subsection{Roselle petal drying}

Old, intact and clean roselle petals were separated from damaged or rotten petals. Flower petals were separated from the seeds and then washed with clean water and then drained. After that drying was done by using a cabinet dryer with a drying time of $7 \mathrm{hrs}$ (Purbowati et al., 2018). Then the dried roselle petals were mashed and filtered with 80 mesh sieves. Roselle powder was then wrapped in a tight plastic to avoid the influence of moisture.

\subsection{The making of roselle tea}

Roselle flower petals powder with various comparisons (w/v) namely 1:100, 4:100, 7:100, and 10:100 were added into $100 \mathrm{~mL}$ of distilled water. These mixtures were then transferred into the microwave and extracted in $250 \mathrm{~W}$ power for 5 mins. Every two minutes of radiation and then rested for one minute to keep the temperature from rising above the boiling point (Purbowati et al., 2016). These mixtures were filtered using Whatman 42 paper, and then the filtrate was added with one of the sugar types used about $10 \%(\mathrm{w} / \mathrm{v})$ from filtrate volume. The solution was stirred until homogenous, stored in a dark glass bottle at refrigerator temperature $\left(4^{\circ} \mathrm{C}\right)$ for $24 \mathrm{hrs}$ until used for analysis.

\subsection{Anthocyanin}

Anthocyanin was determined as described by Fuleki and Francis (1968). An aliquot ( $1 \mathrm{~mL})$ of sample solution was added with $1 \mathrm{~mL}$ of acidic ethanol $(95 \%$ ethanol $+\mathrm{N}$ HCL $(85: 15 \mathrm{v} / \mathrm{v}))$. The sample was stored overnight at $40^{\circ} \mathrm{C}$. The absorbance was measured using $535 \mathrm{~nm}$ wavelength. 


\subsection{Total phenol}

Total phenol was determined using Folin-Ciocalteu method (Chew et al., 2009). About $0.4 \mathrm{~mL}$ of sample solution was added with $1.5 \mathrm{~mL}$ of Folin-Ciocalteu reagent $(10 \% \mathrm{v} / \mathrm{v})$. After being incubated for five minutes, it was mixed with $1.5 \mathrm{~mL}$ of $7.5 \%(\mathrm{w} / \mathrm{v})$ of $\mathrm{Na}_{2} \mathrm{CO}_{3}$ solution. After 90 minutes of incubation in room temperature and dark room, its absorbance was measured using $765 \mathrm{~nm}$. Gallic acid was used as a standard. The result is presented as mg gallic acid equivalent (GAE)/g materials.

\subsection{Color measurement}

The result was expressed in CIEL $* a * b *$ L color space, where $\mathrm{L}$ was lightening, $\mathrm{a} *$ was greenish-reddish, and $\mathrm{b} *$ was bluish-yellowish. $\mathrm{L}$ component was the range from $0-100 \%$ while the $\mathrm{a}^{*}$ and $\mathrm{b}^{*}$ components are in the range from -120 to +120 . Before analysis, calibration to the standard white plate was carried out. Color measurement was done using a color reader CR10.

\subsection{Sensory test}

Sensory test was done to determine hedonic quality towards roselle tea products properties, namely acidity level and preference. Hedonic test was done in 20 semitrained panelists. Numeric values for acidity level were in the scale of 1 to 3 , which 1 was not sour, 2 was slightly sour, and 3 was sour. On the other hand, numeric values for hedonic test were on the scale of 1 to 3 , which 1 was not preferable, 2 was slightly preferable, and 3 was preferable. The data was analyzed with Sensory Attribute Analysis

\subsection{Data analysis}

Test data for total phenol, anthocyanin and sensory were analysed by ANOVA at the level of 5\%. If there is a real influence, continue with Duncan's multiple area test.

\section{Results and discussion}

\subsection{Physical variable of Roselle tea}

\subsubsection{Color}

Color's variable was measured using color reader CR-10 with CIELAB method. Hermawan et al. (2010) stated that CIELAB's color scale was an estimation of color uniformity scale. $\mathrm{L}^{*}$ axis shows brightness level with the scale of 0 (dark) to 100 (bright). $A^{*}$ and $b^{*}$ axis do not have specific limit value. If $\mathrm{a}^{*}$ value is positive, it means red, and negative means green. On the other hand, if $b^{*}$ is negative, it means yellow, and positive means blue. The results of analysis of variance showed that variations in the addition of rosella petals, the type of sugar and the interaction of both did not significantly affect the values of $a^{*}$ and $b^{*}$. However, variations in the addition of rosella flowers significantly affect the value of L.

Figure 1 shows L intensity (brightness) of roselle tea's color declining as the used roselle flower petals ratio increases. These were suspected related to the anthocyanin content in roselle flower petals which was able to give red color to the final result of roselle tea. Chumsri et al. (2008) stated that the addition of dried roselle flower petals $1: 10(\mathrm{w} / \mathrm{v})$ was contributing to produce a brighter red compared to $1: 5$ addition. Furthermore, the ratio of fresh roselle flower petals 1:2 (w/v) produces the least brightness compared to 1:5 and 1:10 addition. These results showed the greater dried fresh roselle flower petals addition, the brighter intensity of red color that can be observed. According to Kharisma et al. (2015), the increasing of anthocyanin content increased the redness level of the extract. The opposite, when the water part of the extraction increased, the $\mathrm{pH}$, total acidity, total dissolved solids, total anthocyanin and total phenol contained within the extract decreased.

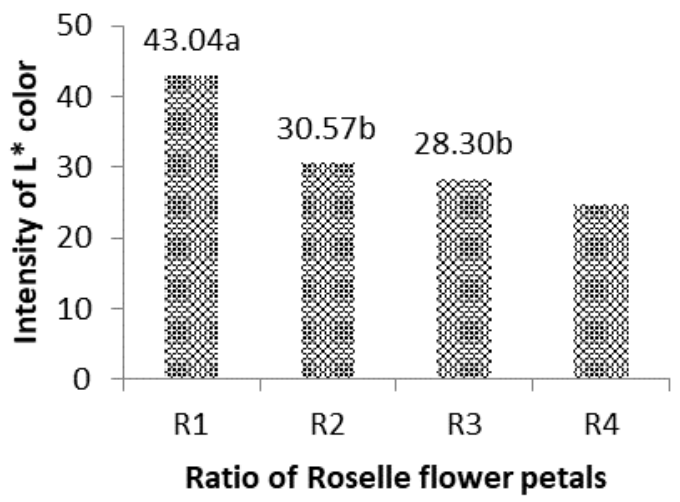

Figure 1. Intensity of $\mathrm{L}^{*}$ color (brightness) based on roselle flower petals' ratio. Same letters above the bars indicate no significant difference.

\subsubsection{The effect of variations in the ratio of Roselle flower petals towards total phenol and anthocyanin in Roselle tea}

Analysis of variance showed that roselle petal and sugar type addition had a very significant effect on total phenol. Whereas only roselle petal addition had a significant effect on anthocyanin. It is shown from Figure 2(a) that the higher ratio of roselle petal flowers, the greater the total phenol content produced. The highest total phenol content was owned by roselle tea which treated by roselle petal addition 10:100 (w/v) with the average value of $24.35 \mathrm{mg} / 100 \mathrm{~mL}$. The increased total phenol content in roselle tea along with the addition of roselle flower petals increased. Li et al. (2009) stated that the optimal parameter for extracting flavonoids from 
mulberry leaves ethanol concentration is $60 \%$, material/ solvent ratio $1: 15$, microwave power is $560 \mathrm{~W}$ and time is 5 minutes. The higher the concentration the higher the extracted flavonoids. These were due to the fact that the increasing material/solvent ratio could decrease solution concentration different inside and outside plant cell which consequently prompted diffusion rate of solute particles and made more flavonoids molecules enter the solution. However, a large amount of solvent resulted flavonoids content in the extract was unnecessary low. Sruthi et al. (2011) stated that roselle flower petals contain flavonoid gossipetin, hibisetin, and sabdaretin. Roselle flower petals contain the total phenol with the concentration of $683.13 \mathrm{mg} / 100 \mathrm{~g}$ (Wu et al., 2018). Sirag et al. (2014) also stated that total phenol of 41.07 $\mathrm{mg} / \mathrm{g}$ is found in roselle flower petals.

(A)

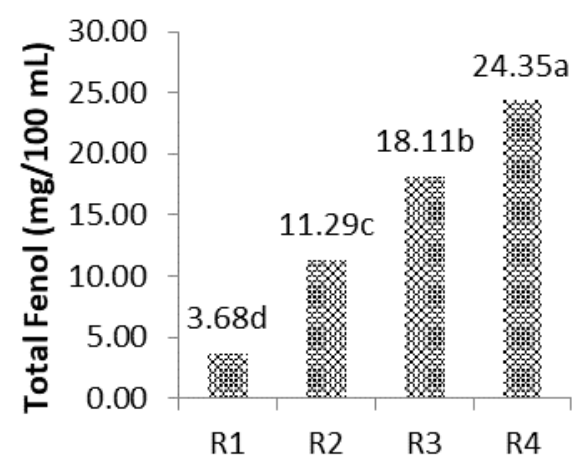

Roselle Flower Petals Ratio

(B)

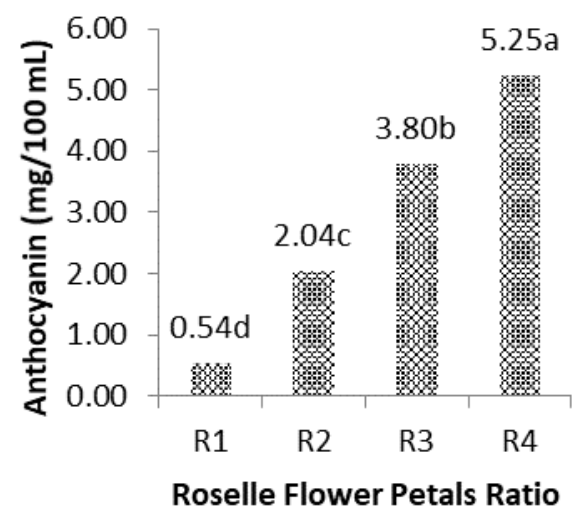

Figure 2. Average value phenol (A) and anthocyanin (B) Roselle tea towards variation of roselle petal flowers ratio. Same letters above the bars indicate no significant difference.

Similar to phenol, total anthocyanin in roselle tea increases along with the increase of roselle flower petals' ratio which can be seen in Figure 2(b). The highest anthocyanin content was found in roselle tea with a $10: 100(\mathrm{w} / \mathrm{v})$ roselle petal flowers addition ratio which is $5.25 \mathrm{mg} / 100 \mathrm{~mL}$. Total anthocyanin in roselle flower petals is $361.99 \mathrm{mg}$ CGE/100 $\mathrm{g}$ (Wu et al., 2018). According to Purbowati et al. (2018), the greater number of dry roselle would cause a greater amount of roselle surface area that come into contact with the solvent. Therefore, the amount of roselle bioactive compound which are the total phenol and anthocyanin extracted will increase.

Figure 3 shows that total phenol content in roselle tea which was produced by coconut sugar addition had the highest total phenol content of $17.29 \mathrm{mg} / 100 \mathrm{~mL}$. That level is significantly different from cane sugar as well as corn sugar. This is suspected that the presence of melanoidin compounds results from the Maillard reaction during coconut sugar manufacture. It is mentioned in Septiana and Dwiyanti (2009) that melanoidin is a polyphenol compound.

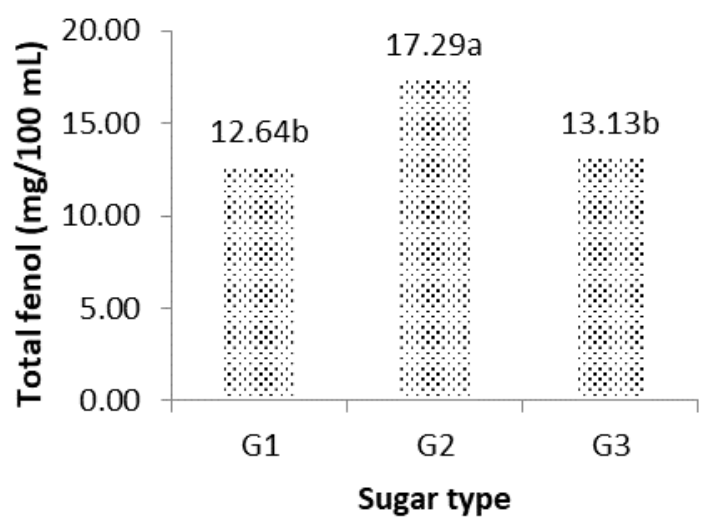

Figure 3. Average value of roselle tea total phenol towards variation of sugar type. Same letters above the bars indicate no significant difference.

Sekarini (2011) stated that total phenol content in green tea drinks with coconut sugar treatment was higher than cane sugar treatment. Coconut sugar has similar manufacture with palm sugar which is only through the heating or the evaporating process without a particular purification, unlike cane sugar manufacture. Purification was carried out in cane sugar manufacture had an effect on decreasing melanoidin levels.

\section{$3.1 .3 \mathrm{pH}$}

Based on analysis of variance, the interaction of variations in the addition of rosella petals and the type of sugar significantly affected the $\mathrm{pH}$ value of the drinks produced. The more roselle petal flowers were added, the lower the $\mathrm{pH}$ value of the drinks produced. This can be seen from the slope value of the linear regression equation for each sugar type was negative. This was because the more roselle powder was added, the wider contact surface with the solvent. As a result, more phenolic compounds in the extract. These were what causes the $\mathrm{pH}$ value decreases. Phenolic compounds found in rosella, which were mostly anthocyanins, can also function as antioxidants. The more phenolic compounds, the more antioxidant compounds in the extract. According to Husni et al. (2014) antioxidant compounds from the phenolic group function as hydrogen donors which will stabilize radical compounds. 


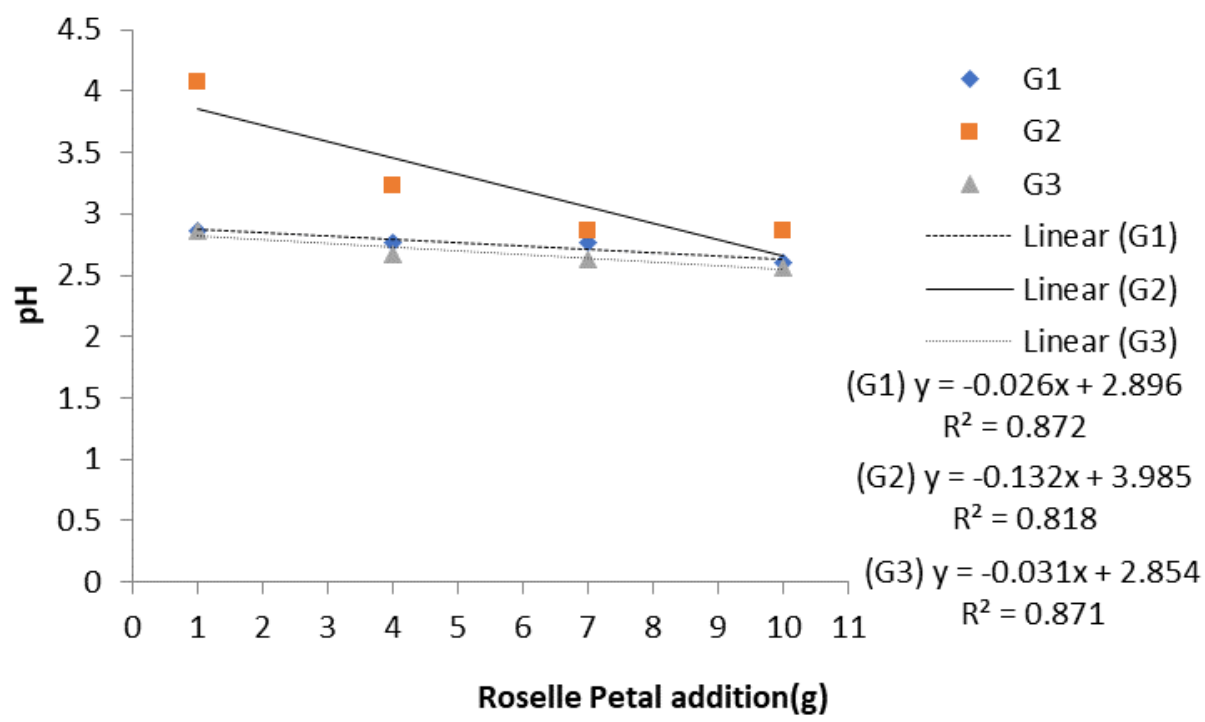

Figure 4. The effect of interaction between roselle petal and sugar type addition to $\mathrm{pH}$ value

This $\mathrm{H}^{+}$ion determines the acidity. The more $\mathrm{H}^{+}$ions caused higher acidity, resulted in lower $\mathrm{pH}$ value.

From Figure 4, it can be seen that the biggest decreased in $\mathrm{pH}$ value was a functional drink with the addition of coconut sugar. This can be seen from the absolute value of the slope of the highest resulting regression equation, which was 0.132 . This value implied that drinks with coconut sugar, the addition of one gram rosella powder would result in a decrease in $\mathrm{pH}$ of 0.132 . According to Karseno et al. (2018), coconut sugar contains phenolic compounds as much as $0.48 \%$. Also, Manzocco et al. (2011) stated that coconut sap contains high reducing sugars and amino acids. The content of phenol compounds is what distinguishes it from cane sugar and corn sugar.

\subsection{Sensory variable of Roselle tea}

\subsubsection{Acidity level}

The analysis of variance showed that roselle petal addition, sugar type and the interaction of both had a very significant effect on the acidity level. Figure 5(a) shows the greater roselle flower petals, the higher level roselle tea acidity produced. According to Abou-Arab et al. (2011), the acidity was caused by several organic acids. Roselle is rich in organic acids, namely citric acid, malic acid, tartaric acid, and allo-hydroxycitric acids (Singh et al., 2017). Maskour et al. (2013) stated that the increased ratio of solids: solvent will increase anthocyanin content within the extract. Purbowati et al. (2018) stated that the greater amount of added roselle, vitamin $\mathrm{C}$ content within roselle extract produced will increase. This was because the amount of the roselle surface which was in contact with the water solvent was higher. Therefore, the amount of extracted vitamin $\mathrm{C}$ will increase.

As seen in Figure 5(b) that corn sugar produces different acidity level compared to cane sugar and coconut sugar. This was suspected due to the corn sugar which has a higher level of sweetness level compared to the other two types of sugar, thus the sour taste of this roselle drink was lower. Corn sugar contains sorbitol as natural sweetener and sucralose as an artificial sweetener. The level of sweetness in sorbitol is relatively similar with 0.5 to 0.7 times of sucrose sweetness level, whereas, sucralose has a relative sweetness level of 6000 times the sweetness of sucrose with no calories. (Badan Standarisasi Nasional, 2004).

(A)

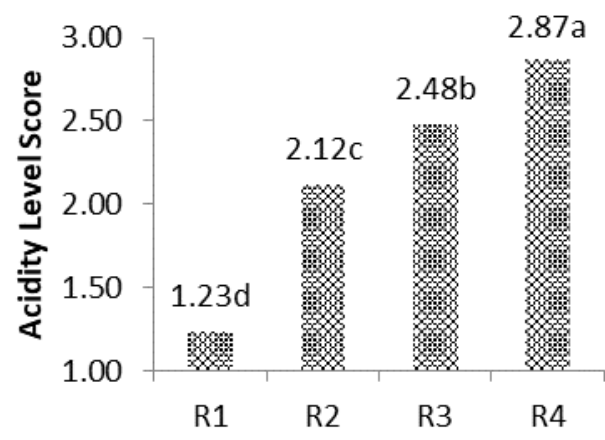

Roselle Flower Petals Ratio

(B)

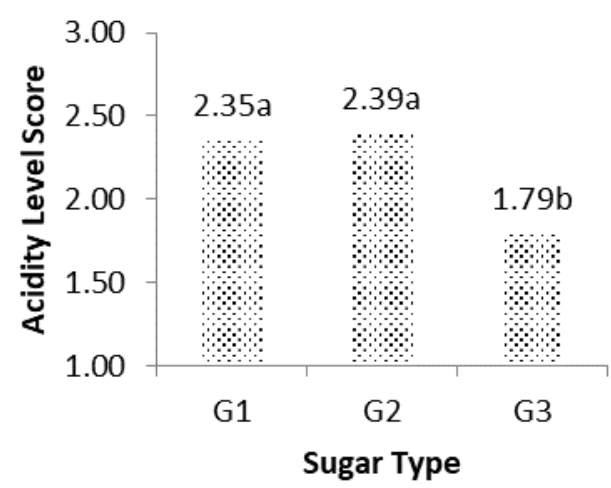

Figure 5. Average value of roselle tea acidity score towards the variation of roselle flower petals (A) and sugar type (B). Same letters above the bars indicate no significant difference. 


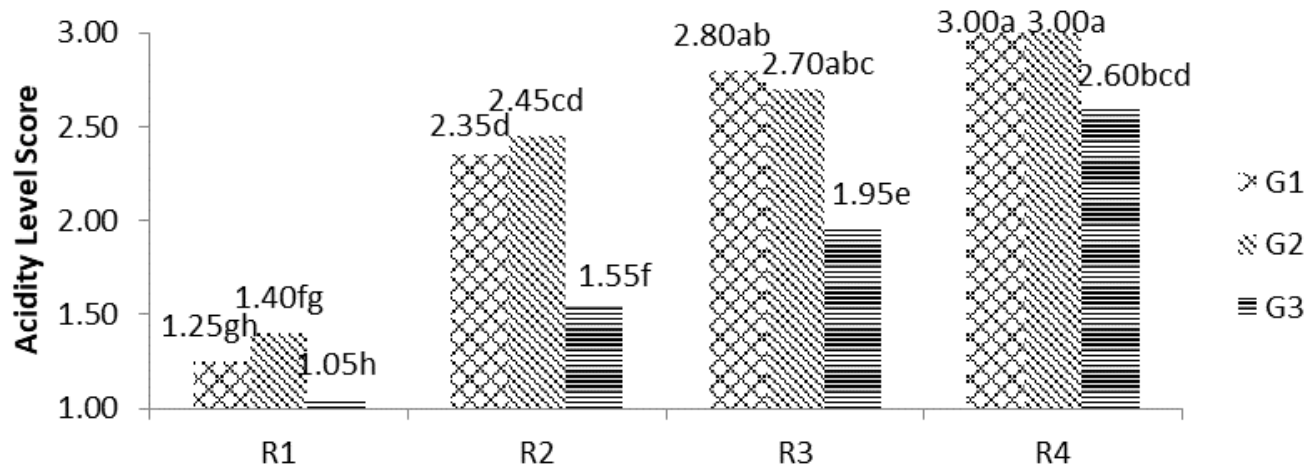

Figure 6. The average value of roselle tea acidity score in combination treatment. Same letters above the bars indicate no significant difference.

The average value of roselle tea acidity score in the combination treatment was shown in Figure 6. From that, it was shown that along with the increased roselle flower petals, the acidity level score will increase. However, in combination treatment with corn sugar has a significantly lower acidity score compared to treatments using two other sugar types. It was stated that the sweetness is caused by corn sugar which overpowers roselle tea acidity.

This study result also shows that the acidity level score for roselle tea drinks which use cane sugar and coconut sugar was not significantly different. Therefore, the use of coconut sugar could replace can sugar to cover the sour taste of roselle. However, the use of coconut sugar was more recommended because of lower glycemic index and the amino acid content naturally found in coconut sugar.

\subsubsection{Preference level}

The variations in roselle petals and the sugar type added significantly affected preference level. Figure 7(a) showed that R1 and R2 ratio were not significantly different, whereas R3 and R4 ratio were significantly different. In terms of sugar type, cane sugar and coconut sugar were not significantly different but were significantly different with corn sugar.

Based on Figure 7, panelists prefer roselle tea with roselle flower petals which have the lowest ratio (R1), as well as using corn sugar. This was due to sour taste caused by roselle flower petals which were not preferred by the panelists. As stated in Mgaya et al. (2014), the acidity level causes sourness within the juice, therefore it needs a sweetener. Due to high acidity, bitterness, and sourness, drinks made from roselle extracts are not accepted by most consumers in Tanzania.

Based on the effectiveness index analysis, the best treatment combination was R4G1 which had the following characteristics: anthocyanin at $5.25 \mathrm{mg} / 100$ $\mathrm{mL}$; phenol of $24.35 \mathrm{mg} / 100 \mathrm{~mL}$; $\mathrm{pH}$ of 2.6 ; $\mathrm{L}$ of 24.70 ; $\mathrm{a}^{*}$ of 5.8 and $\mathrm{b}^{*}$ of 5.71 . This best combination had an organoleptic test score that was the level of preference and acidity respectively as follows: 1.45 (dislike-like) and 3.00 (sour). As a functional drink of Rosella tea, the focus was on the high content of bioactive compounds, namely phenol and anthocyanin compounds. However, for the health benefits to be felt, consumer preferences were still considered an important factor. Septiana et al. (2018) stated that functional food is a food or beverage product containing active compounds that play a role in maintaining the health of the body. In line with Siro et al. (2008) that to provide health benefits, functional food must also be acceptable sensorially.

(A)

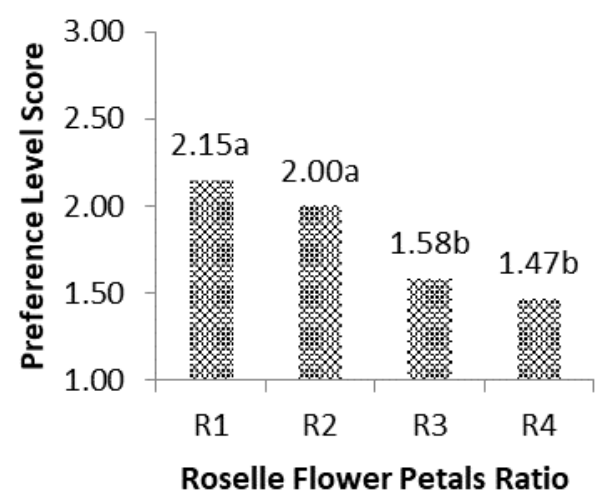

(B)

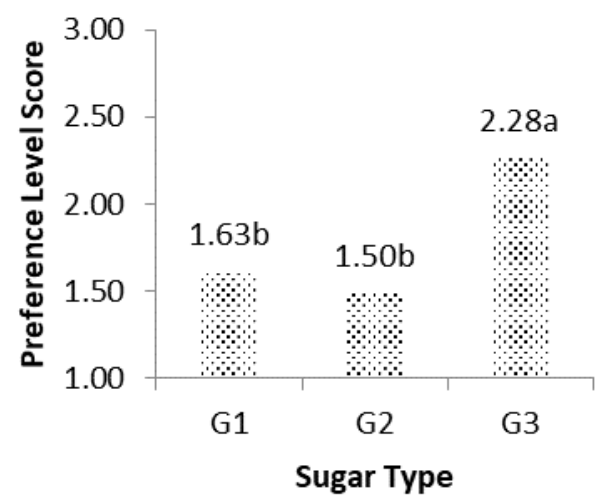

Figure 7. The average value of roselle tea preference level towards the variation of roselle flower petals (A) and sugar type (B). Same letters above the bars indicate no significant difference.

However, this best combination uses cane sugar which has a high glycemic index. Of course, this is not 
recommended for diabetics. But from the statistical results, the use of cane sugar and coconut sugar had no significant effect both on acidity and preference level. Mean that coconut sugar could replace cane sugar from the sensory perspective.

\section{Conclusion}

The best treatment combination was R4G1 which had the following characteristics: anthocyanin at 5.25 $\mathrm{mg} / 100 \mathrm{~mL}$; phenol of $24.35 \mathrm{mg} / 100 \mathrm{~mL}$; $\mathrm{pH}$ of 2.6 ; $\mathrm{L}$ of 24.70 ; $\mathrm{a}^{*}$ of 5.8 and $\mathrm{b}^{*}$ of 5.71 . This best combination had an organoleptic test score that was the level of preference and acidity respectively as follows: 1.45 (not preferable-slightly preferable) and 3.00 (sour).

\section{Conflict of Interest}

The authors declare no conflict of interest.

\section{Acknowledgments}

The research work was funded by Unsoed's with scheme Competency Improvement Research.

\section{References}

Abou-Arab, A.A., Abu-Salem, F.M. and Abou-Arab, E.A. (2011). Physico-chemical properties of natural pigments (anthocyanin) extracted from roselle calyces (Hibiscus sabdariffa). Journal of American Science, 7(7), 445-456.

Awhin, E.P. (2012). The effect of aqueous extract of Hibiscus sabdariffa I, on the activity of alkaline phosphatase and uric acid in the liver of Rattus novergicus. Continental Journal Medical Research, 6(1), 12-15.

Babajide, J.M., Bodunde, J.G. and Salami A.A. (2004). Quality and sensory evaluation of processed calyces of six varietas of Roselle (Hibiscus sabdariffa). Nigerian Journal of Horticultural Science, 9, 110115. https://doi.org/10.4314/njhs.v9i1.3388

Badan Standardisasi Nasional. (2004). Bahan Tambahan Pangan Pemanis Buatan - Persyaratan Penggunaan dalam Produk Pangan. SNI 01-6993-2004. Retrieved on July 9, 2018 from website: pergizi.org [In Bahasa Indonesia].

Cahyadi, W. (2008). Analisis dan Aspek Kesehatan Bahan Tambahan Pangan. Jakarta, Indonesia: Bumi Aksara. [In Bahasa Indonesia].

Chew, Y.L., Goh, J.K. and Lim, Y.Y. (2009). Assessment of in vitro antioxidant capacity and polyfenolic composition of selected medicinal herbs from Leguminosae family in Peninsular Malaysia. Food
Chemistry, 116(1), 13-18. https://doi.org/10.1016/ j.foodchem.2009.01.091

Chumsri, P., Sirichote, A. and Itharat, A. (2008). Studies on the optimum conditions for the extraction and concentration of roselle (Hibiscus sabdariffa Linn.) extract. Songklanakarin Journal of Science and Technology, 30(1), 133-139.

Fuleki, T. and Francis, F.J. (1968). Quantitative methods for anthocyanins, 1. Extraction and determination of total anthocyanin in Cranberries. Journal of Food Science 33(1), 72-77. https://doi.org/10.1111/j.13652621.1968.tb00887.x

Hermawan, R., Hayati, E.K., Budi, U.S. and Barizi, A. (2010). Effect of temperature, $\mathrm{pH}$, on total concentration and color stability of anthocyanin compound extract roselle calyx (Hibiscus sabdariffa L). Alchemy, 2(1), 104-157

Husni, A., Putra, D.R. and Lelana, I.Y.B. (2014). Aktivitas antioksidan Padina $s p$ pada berbagai suhu dan lama pengeringan. Jurnal Pascapanen dan Bioteknologi Kelautan dan Perikanan, 9, 165-173. [In Bahasa Indonesia] https://doi.org/10.15578/ jpbkp.v9i2.109

Karseno, Erminawati, Tri Yanto, Setyowati, R. and Haryanti, P. (2018). Effect of $\mathrm{pH}$ and temperature on browning intensity of coconut sugar and its antioxidant activity. Food Research, 2(1), $32-38$. https://doi.org/10.26656/fr.2017.2(1).175

Kharismawati, A.S., Nurhasanah, N. and Widyaningsih, T.D. (2015). Pengaruh minuman fungsional jelly drink red dragon riut peel and roselle oxidative stress condition. Jurnal Pangan dan Agroindustri, 3(2), 407-416

Li, H., Wang, X.Y., Li, Y., Li, P.H. and Wang, H. (2009). Polyfenolic compounds and antioxidant properties of selected China wines. Journal Food Chemistry, 112(2), 454-460. https://doi.org/10.1016/ j.foodchem.2008.05.111

Maryani, H. and Kristiana, L. (2008). Khasiat dan Manfaat Roselle. Jakarta, Indonesia: Agromedia Pustaka.

Maskour, M., Maghsoudlou and Shahkari, M.H. (2013). Optimization of roselle beverage formulation using respon surface methodology. Quality Assurance and Safety of Crop and Foods, 5(2), 119-129. https:// doi.org/10.3920/QAS2012.0137

Manzocco, L., Calligaris, S., Mastrocola, D., Nicoli, M. and Lerici, C. (2011). Review of nonenzymatic browning and antioxidant capacity in processed food. Trends Food Science and Technology, 11(9100, 340-346. https://doi.org/10.1016/S0924-2244 (01)00014-0 
Mgaya, B.K., Remberg, S.F., Chove, B.E. and Wicklund, T. (2014). Physio-chemical, mineral composition and antioxidant properties of roselle (Hibiscus sabdariffa L.) extract blended with tropical fruit juices. African Journal of Food, Agriculture, Nutrition and Development, 14(3), 8963-8978.

Nerantzaki, A.A., Tsiafoulis, C.G., Charisiadis, P., Kontogianni, V.G. and Gerothanassis, I.P. (2011). Novel determination of the total phenolic content in crude plant extract by the use of $1 \mathrm{H}$ NMR of the OH spectral region. Analytica Chimica Acta, 688(1), 54-60. https://doi.org/10.1016/j.aca.2010.12.027

Purbowati, I.S.M., Syamsu, K., Warsiki, E. and Rukmini, H.S. (2015). Evaluasi Toksisitas, Aktivitas Antibakteri dan AntioksidanKomponen Bioaktif Roselle dengan Variasi Jenis Pelarut. Jurnal Teknologi Industri, 25(2), 182-189.

Purbowati, I.S.M., Syamsu, K., Warsiki, E. and Sri, H. (2016). Stabilitas Senyawa Fenolik dalam Ekstrak dan Nanokapsul Kelopak Bunga Roselle pada Berbagai Variasi pH, Suhu dan Waktu. Agrointek, 10 (1), 31-40. [In Bahasa Indonesia]. https:// doi.org/10.21107/agrointek.v10i1.2023

Purbowati, I.S.M., Sujiman and Maksum, A. (2018). Antibakterial activity of roselle (Hibiscus sabdariffa) extract phenolics compound produced with variying drying methods and duration. Jurnal Teknologi Industri, 28(1), 19-27. [In Bahasa Indonesia].

Olatunji, S.O. and Juwe, I.S. (2013). Awareness and utilization of Sobo drink (extract of hibiscus sabdariffa roselle calyces) by farm families in Aniocha North Local Government Area of Delta State, Nigeria. Journal of Agriculture and Social Research, 13(2), 19-28.

Sekarini, G.A. (2011). Kajian Penambahan Gula dan Suhu Penyajian terhadap Kadar Total Fenol, Kadar Tannin (Katekin) dan Aktivitas Antioksidan pada Minuman Teh Hijau (Camellia sinensis L.). Surakarta, Indonesia: Universitas Sebelas Maret, MSc. Thesis. [In Bahasa Indonesia].

Septiana, A.T. and Dwiyanti, H. (2009). Aktivitas antioksidan minuman fungsional dari irisan buah kering mahkota dewa. Agritech, 29(1), 16-21.

Septiana, A.T., Sitoresmi, I. and Dewi, P.S. (2018). Sensory evaluation, antioxidant activity and total of microbial of tamarind turmeric herbal drink during the storage of refrigerator temperature at various packaging. Food Research, 2(4), 391 - 397. https:// doi.org/10.26656/fr.2017.2(4).030

Singh, P., Khan, M. and Hailemariam, H. (2017). Nutritional and health importance of Hibiscus sabdariffa: A review and indication for research needs. Journal of Nutritional Health and Food Engineering, 6(5), 125-128. https:// doi.org/10.15406/jnhfe.2017.06.00212

Sirag, N., Elhadi, M.M., Algaili, A.M., Hasan, H.M. and Ohaj, M. (2014). Determination of total phenolic content and antioxidant activity of roselle (Hibiscus sabdariffa L.) calyx ethanolic extract. Standard Research Journal of Pharmacy and Pharmacology, 1 (2), 34-39.

Siro, I., Kapolna, E., Kapolna, B. and Lugasi, A. (2008). Functional food: Product development, marketing, and consumer acceptance-A review. Appetite, 51(3), 456-467. https://doi.org/10.1016/j.appet.2008.05.060

Wang, Y., Xi, G.S., Zheng, Y.C. and Miao, F.S. (2010). Microwave assisted extraction of flavonoids from Chinese herb radix puerariae (Ga gen). Journal of Medicinal Plant Research, 4(4), 304-308.

Wu, H. Y., Yang, K.M. and Chiang, P.Y. (2018). Roselle anthocyanins: Antioxidant properties and stability to heat and $\mathrm{pH}$. Molecules, 23(6), 1357. https:// doi.org/10.3390/molecules23061357

Zhang, F., Chen, B., Xiao, S. and Yao, S. (2005). Optimization and comparison of different extraction Techniques for sanguinarine and chelerythrine in fruits of Macleaya cordata (Wild) R.Br. Separate Purification Technology, 42(3), 283-290. https:// doi.org/10.1016/j.seppur.2004.09.002 